New Zealand Journal of Forestry Science

\title{
Comparison of cost, productivity and residue yield of cut-to-length and fuel-adapted harvesting in a Pinus radiata D.Don final harvest in Western Australia
}

\author{
Martin Strandgard ${ }^{1,2, *}$ and Rick Mitchell ${ }^{2}$ \\ ${ }^{1}$ University of Tasmania, Churchill Avenue, Sandy Bay, Tasmania, 7005, Australia \\ ${ }^{2}$ University of the Sunshine Coast, Locked Bag 4, Maroochydore DC, Queensland, 4558 Australia \\ *Corresponding author: mstrandg@usc.edu.au \\ (Received for publication 26 September 2018; accepted in revised form 24 July 2019)
}

\begin{abstract}
Background: Forest biomass is a major global source of biofuel. To compete with other energy sources its delivered costs need to be reduced. Globally, logging residue (LR) is likely to be the cheapest, readily available forest biomass form. LR transport is a major cost component.

Methods: A harvester-forwarder harvest system was studied in two adjacent areas to compare Swedish "fuel-adapted harvesting" with conventional cut-to-length harvesting at the stump in a mature Pinus radiata D.Don plantation in Western Australia to assess the impact of fuel-adapted harvesting on costs and productivity of a harvester and forwarder producing logs and extracting LR and on LR yield.

Results: Harvester and forwarder productivities producing logs were significantly reduced in the fuel-adapted area compared with the conventional area which increased log production costs for the fuel-adapted site by $15 \%$.

Forwarder productivity extracting LR and LR yield were significantly greater in the fuel-adapted area which reduced LR extraction costs by approximately $28 \%$. This was due to the ease of loading LR from residue piles created during fueladapted harvesting compared with loading scattered residue from conventional harvesting.

The cost reduction for LR extraction from the fuel-adapted area exceeded the increased log harvest and extraction costs. This resulted in the combined log and LR costs for the fuel-adapted area being approximately $12 \%$ lower than those for the conventional area. Increased forwarder productivity through adoption of larger load bunks and residue-specific grapples combined with increased operator experience with fuel-adapted harvesting would be likely to further decrease log and LR production costs.

Conclusions: The results show that adoption of fuel-adapted harvesting could reduce LR delivered costs, thus increasing its viability as a biofuel. However, primary transport cost is only one component of LR delivered costs and needs to be considered in combination with the reduction of other supply chain costs, particularly secondary transport costs which can make up a large proportion of LR delivered costs.

Because removal of most LR from a site can reduce subsequent tree growth, guidelines specifying the proportion of LR retained should be considered.
\end{abstract}

Keywords: Logging residue, bioenergy, fuel-adapted harvesting, Pinus radiata, harvester, forwarder

\section{Introduction}

Forest biomass is a major energy source in many countries, supplying over $25 \%$ of the energy needs of Sweden, Finland and Austria (AEBIOM 2013). Estimates of worldwide forest biomass availability suggest that there is sufficient unused forest biomass to provide a substantial proportion of global energy needs (Gregg \& Smith 2010). 
For forest biomass to compete with conventional energy sources, its delivered costs must be minimised (Caputo et al. 2005). Sawmill residues are likely to be the cheapest form of forest biomass as they do not incur costs for collection and transport from the harvest site (Mani et al. 2006). However, sawmill residues are often already used in pulp or particle board manufacture or as fuel on the sawmill site (Parikka 2004). Logging residue (LR) is the next cheapest form of forest biomass (Rodriguez et al. 2011). Globally it is estimated that there are several hundred million tonnes of LR potentially available annually after excluding LR retained to maintain site productivity or uneconomic to extract (Gregg \& Smith 2010).

The low bulk density, low energy density and high moisture content of fresh LR (Wolfsmayr and Rauch 2014) increase its transport costs relative to conventional energy sources (Gold \& Seuring 2011). LR from harvest operations where trees are processed at roadside generally has the lowest delivered costs as primary transport costs are minimised (Belart et al. 2017; Yemshanov et al. 2014). However, primary transport can form a significant component of delivered costs for LR arising from cut-to-length (CTL) at the stump harvest operations, which is a commonly employed harvest system world-wide.

During conventional CTL harvest operations trees are processed in front of the harvester causing LR to mainly fall in the harvester's path which can help reduce soil compaction (Cambi et al. 2015). However, this practice makes it difficult to collect the LR and increases its soil contamination (Kizha and Han 2016). This, in turn, increases wear and tear on equipment used to process LR into bioenergy and the ash content when this material is burned. In contrast, concentration of LR into piles or windrows can increase LR primary transport productivity (Cuchet et al. 2004). One such method developed in Sweden is called fuel-adapted harvesting; which involves the harvester processing trees at its side so that LR is placed between log piles. Fuel-adapted harvesting has been shown to increase the proportion of LR extracted from a site (Jacobson \& Filipsson 2013) and reduce contamination from attached soil (Junginger et al. 2005).

The objective of this trial was to compare the current harvesting method with the Swedish 'fuel-adapted' harvesting method in terms of harvester and forwarder cost, productivity, and the yield of LR extracted from a cut-to-length, final harvest operation in a mature $P$. radiata D.Don stand.

\section{Methods \\ Study area}

The study was conducted in October/November 2017 in a 29-year-old Pinus radiata plantation $80 \mathrm{~km}$ south-east of Manjimup, Western Australia (34.47966S, 116.75446E) managed by the Forest Products Commission (FPC). The plantation had been first thinned at age 15 years and had subsequently suffered sporadic windthrow over approximately $80 \%$ of its area. Soil was a duplex sandy gravel and maximum slope was 5 degrees. Weather during the study was generally fine with light rain falling on several days ( $<3 \mathrm{~mm}$ in total).

The study site was divided into two adjacent areas: a 2.96 ha area harvested using a conventional harvester/ forwarder cut-to-length harvest system (the Conventional area) and a 3.38 ha area harvested with a harvester and forwarder using the Swedish "fuel-adapted" harvest system (the Fuel-adapted area). Diameter at breast height over bark (DBHOB) was measured on 107 trees in the Conventional area and on 104 trees in the Fueladapted area. The total height of approximately one-third of these trees was measured using a vertex hypsometer (Haglöf, Sweden). Each measured tree was numbered with paint for identification during the time and motion study. Unmeasured tree heights were predicted using a height/diameter relationship developed from the trial site data. Individual tree volumes were estimated using a tree volume function supplied by the plantation manager. Stand and site characteristics are shown in Table 1.

Retained LR quantities were measured using $1 \mathrm{~m}^{2}$ plots placed at randomly-selected intersection points on grids covering each area. Estimated weights of retained LR (Mg ha ${ }^{-1}$ ) were then calculated by multiplying the mean LR weight for the plots within each site by 10 to convert $\mathrm{kg} \mathrm{m}^{-2}$ to $\mathrm{Mg} \mathrm{ha}^{-1}$.

\section{Harvesting procedures}

In both trial areas the harvester travelled along the planting rows. In the Conventional area trees were felled into the unharvested plantation to the right of the harvester and processed so that the logs were piled in

TABLE 1. Stand and site characteristics for the Conventional and Fuel-adapted study sites

\begin{tabular}{|c|c|c|}
\hline Parameter & $\begin{array}{l}\text { Conventional } \\
\text { site }\end{array}$ & $\begin{array}{c}\text { Fuel- } \\
\text { adapted } \\
\text { site }\end{array}$ \\
\hline Mean DBHOB (mm) & 396 & 389 \\
\hline Mean height (m) & 27 & 26.6 \\
\hline Mean tree volume $\left(\mathrm{m}^{3}\right)$ & 1.2 & 1.2 \\
\hline Stems per hectare (sph) & 293 & 293 \\
\hline \multicolumn{3}{|l|}{$\begin{array}{l}\text { Total log volume } \\
\text { extracted }\end{array}$} \\
\hline$\left(\mathrm{m}^{3}\right)$ & 650 & 771 \\
\hline$\left(\mathrm{m}^{3} \mathrm{ha}^{-1}\right)$ & 220 & 228 \\
\hline \multicolumn{3}{|l|}{ Recovered residues } \\
\hline Green/Oven dry (Mg) & $126 / 58$ & $196 / 91$ \\
\hline $\begin{array}{l}\text { Green/Oven dry } \\
\left.\left(\mathrm{Mg} \mathrm{ha}^{-1}\right)\right)\end{array}$ & $43 / 20$ & $58 / 27$ \\
\hline$\%$ of total & 42 & 68 \\
\hline \multicolumn{3}{|l|}{ Retained residues } \\
\hline Green/Oven dry (Mg) & $181 / 83$ & $95 / 44$ \\
\hline $\begin{array}{l}\text { Green/Oven dry } \\
\left(\mathrm{Mg} \mathrm{ha}^{-1}\right)\end{array}$ & $61 / 28$ & $28 / 13$ \\
\hline$\%$ of total & 58 & 32 \\
\hline
\end{tabular}


the harvested area to the harvester's left (Figure 1(a)). Most LR fell in front of the harvester. In the Fuel-adapted area trees were felled into the unharvested trees in front of the harvester and processed to its left side so that logs and residues were piled separately adjacent to the harvester's travel path (Figure 1(b)). Approximately six to seven trees were processed to form each log and residue pile in the Fuel-adapted area.

Logs were extracted to roadside by forwarder from each site and piled separately by log product. Five log products were cut on each site using the same product definitions. The mean volumes of the different log products were estimated from StanForD pri files (www. skogforsk.se). These were: short sawlogs ( $3.1 \mathrm{~m} \& 3.7 \mathrm{~m}$ ) $0.25 \mathrm{~m}^{3}$, medium sawlogs $(4.3 \mathrm{~m} \mathrm{\&} 4.9 \mathrm{~m}) 0.34 \mathrm{~m}^{3}$, long sawlogs $(5.5 \mathrm{~m} \& 6.1 \mathrm{~m}) 0.47 \mathrm{~m}^{3}$, export logs $0.14 \mathrm{~m}^{3}$, chiplogs $0.13 \mathrm{~m}^{3}$. Of 42 forwarder cycles studied in each area, six loads had assortments of more than one product type in the Conventional area and 18 loads in the Fueladapted area. Quantities of logs and LR extracted from each area are shown in Table 1.

\section{Log harvest time and motion study}

Harvesting was performed by an experienced operator using a John Deere 903KH single grip harvester (7600 engine hours) with a Waratah 624C harvester head.

A detailed time and motion study was performed in both areas to quantify any differences in harvester performance between them. Harvester cycle and elemental times (Table 2) were recorded on a tablet using UMTPlus time study software (www.laubrass. com/umtplus). Delay times were excluded from cycle times. (a)

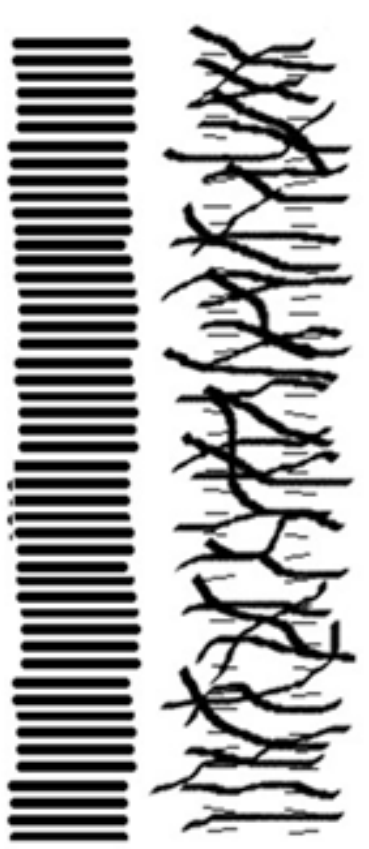

(b)

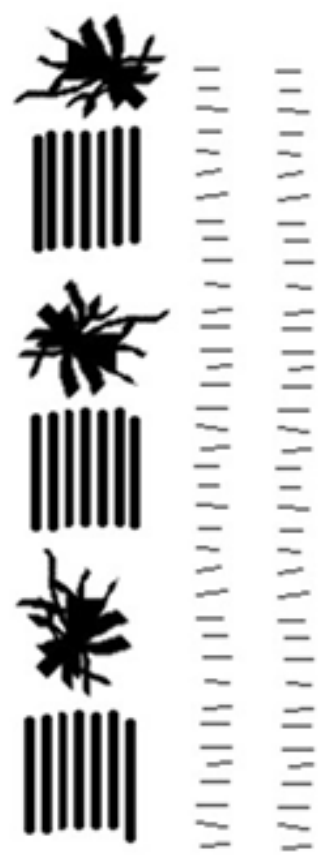

FIGURE 1. Log and logging residue arrangements on the (a) Conventional site; (b) Fuel-adapted site.
TABLE 2. Harvester time element descriptions used in the study

\begin{tabular}{|c|c|}
\hline Time Element & Description \\
\hline $\begin{array}{l}\text { Moving/ } \\
\text { Positioning }\end{array}$ & $\begin{array}{l}\text { Starts when tracks begin to move } \\
\text { or when boom begins its swing } \\
\text { towards next tree. Ends when felling } \\
\text { commences. }\end{array}$ \\
\hline Felling & $\begin{array}{l}\text { Starts when head clamps onto tree. } \\
\text { Ends when feed rollers are activated } \\
\text { or tree is horizontal. }\end{array}$ \\
\hline Processing & $\begin{array}{l}\text { Starts when feed rollers are } \\
\text { activated. Delimbing and cross- } \\
\text { cutting of tree. Ends when felling } \\
\text { boom begins to swing to next tree or } \\
\text { tracks begin to move. }\end{array}$ \\
\hline $\begin{array}{l}\text { Brushing/ } \\
\text { Clearing }\end{array}$ & $\begin{array}{l}\text { Clearing of unmerchantable trees or } \\
\text { processing debris/undergrowth. }\end{array}$ \\
\hline $\begin{array}{l}\text { Stacking/ } \\
\text { Bunching }\end{array}$ & $\begin{array}{l}\text { Starts when the boom commences } \\
\text { moving to retrieve, move or 'stack' } \\
\text { any processed logs. Ends when } \\
\text { another element commences }\end{array}$ \\
\hline Delay & $\begin{array}{l}\text { Any interruption causing the } \\
\text { harvester to cease working during a } \\
\text { shift. }\end{array}$ \\
\hline
\end{tabular}

Harvester productivity $\left(\mathrm{m}^{3}\right.$ per Productive Machine Hour delay free) $\left(\mathrm{m}^{3} \mathrm{PMH}_{0}^{-1}\right)$ was determined by dividing tree volume $\left(\mathrm{m}^{3}\right)$ by delay-free cycle time $\left(\mathrm{PMH}_{0}\right)$ for each tree. Based on the method described by Nurminen et al. (2006), the sum of the time for elements not assigned to a specific cycle (Brushing/Clearing and Stacking/ Bunching) in each area was divided by the number of trees studied in that area and this time was added to the cycle time for each tree. Regression models with tree volume as the independent variable and harvester productivity as the dependent variable were fitted for each area.

\section{Log and logging residue extraction time and motion study}

In both areas, log extraction was undertaken by an experienced operator using a John Deere 1910E forwarder (load capacity $19 \mathrm{Mg}$ ) (3400 engine hours). A different experienced operator, using the same model forwarder (5000 engine hours) carried out the LR extraction in both areas. LR weights were reported on both a green $(53.5 \% \mathrm{MC})$ and oven dry basis.

Log extraction cycle and elemental times (Table 3) were recorded on a tablet during the trial using UMTPlus time study software (www.laubrass.com/umtplus). LR extraction cycle and elemental times (Table 3) were recorded from digital video recordings. Delay times were excluded from cycle times. Loading and Unloading elemental times were expressed both as minutes and minutes per cubic metre (logs) or megagrams (LR) to remove the effect of load size variations. For log extraction, load volumes were estimated by multiplying the number of logs per load of each product type (counted during unloading) by the product type's mean 
TABLE 3. Forwarder time element descriptions (Log and LR extraction) used in the study

\begin{tabular}{|c|c|}
\hline Time Element & Description \\
\hline Travel Empty & $\begin{array}{l}\text { Starts when forwarder } \\
\text { commences travel into the } \\
\text { harvest area from the landing } \\
\text { and ends when crane commences } \\
\text { moving to collect logs/LR. }\end{array}$ \\
\hline Loading & $\begin{array}{l}\text { Starts when crane commences } \\
\text { moving to collect logs/ } \\
\text { LR and ends when another } \\
\text { element commences. Includes } \\
\text { adjustments to the logs/LR on } \\
\text { the bunk. }\end{array}$ \\
\hline $\begin{array}{l}\text { Moving During } \\
\text { Loading }\end{array}$ & $\begin{array}{l}\text { Movement between logs/LR piles } \\
\text { with no crane movement. Starts } \\
\text { when wheels begin rotating and } \\
\text { ends when crane recommences } \\
\text { movement. Simultaneous crane } \\
\text { and wheel movement is recorded } \\
\text { as loading. }\end{array}$ \\
\hline Travel Loaded & $\begin{array}{l}\text { Starts with travel to the landing } \\
\text { with a load and ends when } \\
\text { wheels cease to rotate or crane } \\
\text { commences to move at the } \\
\text { landing. }\end{array}$ \\
\hline Unloading & $\begin{array}{l}\text { Starts with commencement } \\
\text { of crane movement, grapple } \\
\text { empty, towards the forwarder's } \\
\text { bunk and ends when another } \\
\text { element commences. Includes } \\
\text { adjustments to the log/LR stack. }\end{array}$ \\
\hline $\begin{array}{l}\text { Moving During } \\
\text { Unloading }\end{array}$ & $\begin{array}{l}\text { Movement between log/LR } \\
\text { stacks at the landing with no } \\
\text { crane movement. Starts when the } \\
\text { wheels begin to rotate and ends } \\
\text { when the crane recommences } \\
\text { movement to the forwarder } \\
\text { bunk. Simultaneous crane and } \\
\text { wheel movement is recorded as } \\
\text { unloading. }\end{array}$ \\
\hline $\begin{array}{l}\text { Brushing/ } \\
\text { Clearing }\end{array}$ & $\begin{array}{l}\text { Clearing of non-merchantable } \\
\text { trees/undergrowth or processing } \\
\text { debris. }\end{array}$ \\
\hline $\begin{array}{l}\text { Stacking/ } \\
\text { Bunching }\end{array}$ & $\begin{array}{l}\text { Adjustment of logs/LR in a } \\
\text { roadside stack not associated } \\
\text { with unloading or loading. }\end{array}$ \\
\hline Delay & $\begin{array}{l}\text { Any interruption causing the } \\
\text { forwarder to cease working } \\
\text { during a shift. }\end{array}$ \\
\hline
\end{tabular}

log volume. LR load weights were obtained using the forwarder's crane scales. Forwarder productivity was estimated by dividing load volume $\left(\mathrm{m}^{3}\right)$ (log extraction) or load weight (Mg - oven dry and green) (LR extraction) by delay-free cycle time $\left(\mathrm{PMH}_{0}\right)$ for each forwarder cycle.

A Global Positioning System (GPS) equipped Multidat onboard computer (Brown et al. 2002) was installed in the forwarders to estimate their travel distances. Extraction distance was defined as half the total cycle distance (Tiernan et al. 2004).

\section{Statistical analysis}

Linear regression models were developed to understand the key factors associated with harvester and forwarder (logs and LR) cycle times and productivities in the Conventional and Fuel-adapted areas. These models were used to investigate potential relationships between different measures of forwarder productivity (cycle times (min), elemental times ( $\mathrm{min}$ and $\mathrm{min} \mathrm{m}^{-3}$ ) and productivity $\left(\mathrm{m}^{3} \mathrm{PMH}_{0}^{-1}\right)$ ) and characteristics of the operation (extraction distance $(\mathrm{m})$, load volume $\left(\mathrm{m}^{3}\right)$ or load weight (Mg (oven dry)). For log extraction only, potential relationships between productivity measures and either the number of logs per load or number of product types per load were examined. The goodness of fit of these regression models was assessed using $\mathrm{R}^{2}$, Root Mean Square Error (RMSE) and the behaviour of residuals. All models were checked for compliance with the linear regression assumptions. For regressions with multiple independent variables, multi-collinearity was tested using a variance inflation factor (VIF) threshold of five. When the dependent regression variable was logtransformed, the model was corrected for bias (Snowdon 1991) and fit statistics were derived from backtransformed values. Conventional and Fuel-adapted area regression models for each machine were compared statistically using an F test (Motulsky \& Christopoulos 2004).

For each machine, mean cycle and elemental times were compared between the Conventional and Fueladapted areas using t-tests. All comparisons were made at $\mathrm{p}<0.05$. Analysis was performed using MS Excel 2016 and Minitab v. 17.

\section{Costs}

Machine costs $\left(\mathrm{m}^{3} \mathrm{PMH}_{0}^{-1}\right.$ and $\mathrm{Mg}$ (green) $\mathrm{PMH}_{0}^{-1}$ ) were calculated following the method developed by Miyata (1980) using cost assumptions provided in Table 4 and are presented in Australian dollars (AUD).

\section{Results \\ Harvester time consumption and productivity}

For both sites, a natural log - linear model gave the best fit to the cycle time data and a natural log - log model gave the best fit to the productivity data (Table 5).

Mean harvester cycle times (Conventional $1.00 \mathrm{~min}$; Fuel-adapted: $1.10 \mathrm{~min}$ ) and cycle time regression models (Figure 2) were significantly different. Times for the Moving/Positioning and Felling elements were significantly longer in the Fuel-adapted area than in the Conventional area (Table 6). Processing time accounted for the greatest proportion of cycle time in both areas (Conventional: 65.8\%; Fuel-adapted: 68.9\%). Mean harvester productivities (Conventional: $73.8 \mathrm{~m}^{3}$ $\mathrm{PMH}_{0}{ }^{-1}$; Fuel-adapted: $\left.62.7 \mathrm{~m}^{3} \mathrm{PMH}_{0}^{-1}\right)$ and harvester productivity regression models (Figure 3) were also significantly different. 
TABLE 4. Machine cost calculation assumptions used in the study

\begin{tabular}{|c|c|c|}
\hline Machine variable & Harvester & Forwarder \\
\hline Purchase price (AUD) & 750,000 & 700,000 \\
\hline Operating Days Per Year & 249 & 249 \\
\hline Shifts per Day & 1 & \\
\hline Hours per Shift & 10.0 & 10.0 \\
\hline Utilisation rate (\%) & 70 & 75 \\
\hline Machine life (years) & 5 & \\
\hline $\begin{array}{l}\text { Salvage Value ( } \% \text { of } \\
\text { purchase price) }\end{array}$ & 20 & 2 \\
\hline $\begin{array}{l}\text { Repair and Maintenance } \\
\text { (\% of depreciation) }\end{array}$ & 75 & 75 \\
\hline $\begin{array}{l}\text { Interest Rate (\% } \\
\text { of average yearly } \\
\text { investment) }\end{array}$ & 9 & \\
\hline $\begin{array}{l}\text { Insurance and Tax Rate } \\
\text { ( } \% \text { of average yearly } \\
\text { investment) }\end{array}$ & 6 & \\
\hline Fuel Cost $\left(\text { AUD L L }^{-1}\right)^{*}$ & 0.98 & 0.98 \\
\hline $\begin{array}{l}\text { Oil \& Lubricant (\% of fuel } \\
\text { cost) }\end{array}$ & 50 & 50 \\
\hline Labour costs (AUD SMH'-1) & 46.59 & 46.59 \\
\hline $\begin{array}{l}\text { Supervision (\% of Labour } \\
\text { Costs) }\end{array}$ & 10 & 10 \\
\hline
\end{tabular}

* At time of study off-road vehicle use in Australia was eligible for a tax rebate of AUD0.403 litre $^{-1}$

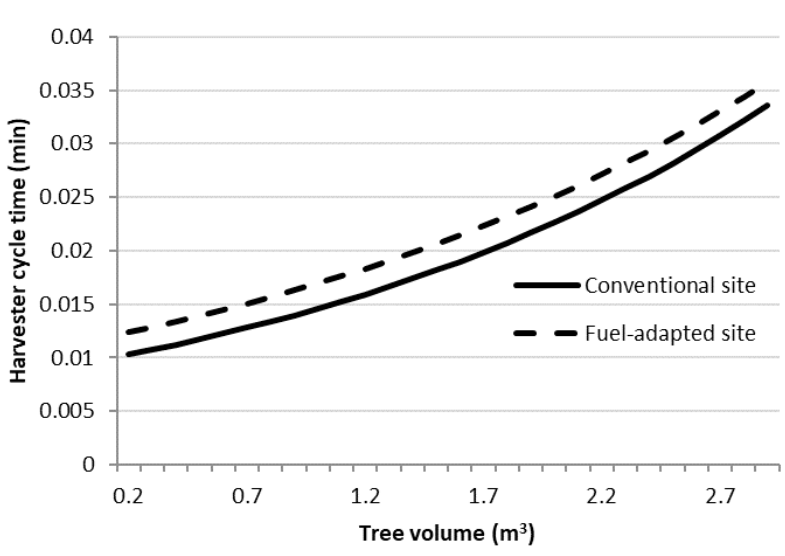

FIGURE 2: Harvester cycle time regression models for the Conventional and Fuel-adapted study sites.

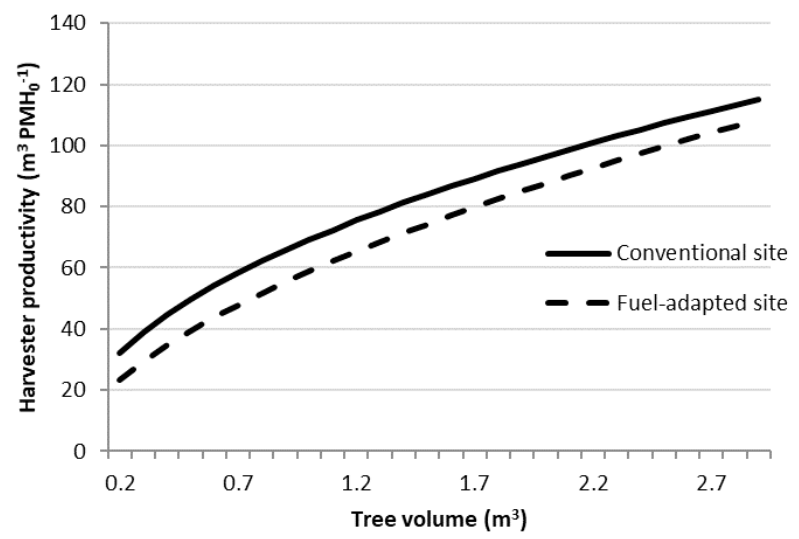

FIGURE 3: Harvester productivity regression models for the Conventional and Fuel-adapted study sites.

TABLE 5. Harvester cycle time and productivity regression models and fit statistics

\begin{tabular}{|c|c|c|c|c|}
\hline Site & Model & Sample size & RMSE & $\mathbf{R}^{2}$ \\
\hline \multirow[t]{2}{*}{ Conventional } & Cycle time $=0.0094^{*} \exp ^{0.44 *}$ Tree Volume & 107 & 0.003 & 0.59 \\
\hline & Productivity $=68.1^{*}$ Tree Volume ${ }^{0.47}$ & 107 & 14.2 & 0.53 \\
\hline \multirow[t]{2}{*}{ Fuel-adapted } & Cycle time $=0.0114^{*} \exp ^{0.39 *}$ Tree Volume & 104 & 0.004 & 0.41 \\
\hline & Productivity $=58.8^{*}$ Tree Volume ${ }^{0.57}$ & 104 & 11.5 & 0.60 \\
\hline
\end{tabular}

Table 6. Harvester mean elemental times ( $\mathrm{min}$ ) for the Conventional and Fuel-adapted study sites.

\begin{tabular}{lccccc}
\hline Site & Moving/Positioning & Felling & Processing & Brushing/Clearing & Stacking \\
\hline Conventional & $0.13^{*}$ & $0.11^{*}$ & 0.65 & 0.07 & 0.028 \\
Fuel-adapted & $0.17^{*}$ & $0.13^{*}$ & 0.69 & 0.09 & 0.026 \\
\hline
\end{tabular}

\footnotetext{
* Significantly different elemental times between sites
} 


\section{Log extraction time consumption and productivity} Time elements not assigned to a specific cycle (Brushing/Clearing and Stacking/Bunching) were excluded from cycle times as they made up less than $1 \%$ of total forwarder study time at each site. In both areas, linear regression models gave the best fit to the forwarder cycle time and productivity data (Table 7). Interaction terms were not significant and VIF values were less than 5 . In both areas, load volume explained the greatest proportion of the variability in cycle time and productivity.

Mean forwarder cycle times (Conventional: 24.1 min; Fuel-adapted: $31.2 \mathrm{~min}$ ) and the cycle time and productivity regression models were significantly different between areas. Moving during loading, Travel loaded, and Moving during unloading elemental times were significantly longer in the Fuel-adapted area (Table 8). Loading and Unloading times were also significantly longer in the Fuel-adapted area when expressed in minutes but were not significantly different when expressed in $\min \mathrm{m}^{-3}$.

Mean extraction distance in the Fuel-adapted area (298 m) was significantly longer than in the Conventional area $(236 \mathrm{~m})$. Mean load volume and number of logs were not significantly different between areas (Conventional: $15.6 \mathrm{~m}^{3}$ and 64 logs; Fuel-adapted: $17.7 \mathrm{~m}^{3}$ and 70 logs). For the pooled mean extraction distance $(267 \mathrm{~m})$, load volume (16.6 $\left.\mathrm{m}^{3}\right)$ and log number (67) across both area,

TABLE 7. Forwarder cycle time and productivity regression coefficients and fit statistics

\begin{tabular}{|c|c|c|c|c|}
\hline \multicolumn{2}{|l|}{ Site } & \multirow{2}{*}{$\begin{array}{c}\text { Sample size } \\
42\end{array}$} & \multirow{2}{*}{$\begin{array}{c}\text { RMSE } \\
2.21\end{array}$} & \multirow{2}{*}{$\begin{array}{c}\mathbf{R}^{2} \\
0.85\end{array}$} \\
\hline Conventional & $\begin{array}{l}\text { Cycle time }=1.27+0.77 \times \text { Load volume }+0.092 \times \text { Log number }+0.021 \times \\
\text { Extraction distance }\end{array}$ & & & \\
\hline & $\begin{array}{l}\text { Productivity }=33.4+1.2 \times \text { Load volume }-0.035 \times \text { Extraction distance }- \\
0.092 \times \text { Log number }\end{array}$ & 42 & 3.49 & 0.82 \\
\hline \multirow[t]{2}{*}{ Fuel-adapted } & $\begin{array}{l}\text { Cycle time }=5.0+0.69 \times \text { Load volume }+0.085 \times \text { Log number }+0.027 \times \\
\text { Extraction distance }\end{array}$ & 42 & 4.01 & 0.52 \\
\hline & $\begin{array}{l}\text { Productivity }=24.6+1.26 \times \text { Load volume }-0.032 \times \text { Extraction distance }- \\
0.051 \times \log \text { number }\end{array}$ & 42 & 3.77 & 0.81 \\
\hline
\end{tabular}

TABLE 8. Regression models, associated $\mathrm{R}^{2}$ values and mean times for each forwarder time element (extracting logs) at the Conventional and Fuel-adapted study sites.

\begin{tabular}{|c|c|c|c|c|}
\hline Time element & Site & Regression & $\mathbf{R}^{2}$ & $\begin{array}{l}\text { Mean time } \\
(\mathrm{min})\end{array}$ \\
\hline \multirow[t]{2}{*}{ Travel empty (min) } & Conventional & $0.0064 \times$ Extraction distance & 0.74 & 1.51 \\
\hline & Fuel-adapted & No significant relationship & - & 1.90 \\
\hline \multirow[t]{2}{*}{ Loading $\left(\operatorname{min~} \mathrm{m}^{-3}\right)$} & Conventional & $0.83-0.0195 \times$ Load volume $+0.0042 \times$ Log number & 0.61 & 0.80 \\
\hline & Fuel-adapted & $1.42-0.024 \times$ Load volume $-0.081 \times$ Product number & 0.58 & 0.85 \\
\hline \multirow[t]{2}{*}{ Loading (min) } & Conventional & $0.44 \times$ Load volume $+0.073 \times$ Log number & 0.98 & $11.5^{*}$ \\
\hline & Fuel-adapted & $3.7+0.37 \times$ Load volume $+0.055 \times$ Log number & 0.50 & $14.1^{*}$ \\
\hline \multirow[t]{2}{*}{$\begin{array}{l}\text { Moving during } \\
\text { loading (min) }\end{array}$} & Conventional & $0.012 \times$ Extraction distance & 0.76 & $2.82 *$ \\
\hline & Fuel-adapted & $0.064 \times \log$ number & 0.83 & $4.44^{*}$ \\
\hline \multirow[t]{2}{*}{ Travel loaded (min) } & Conventional & $0.67+0.0058 \times$ Extraction distance & 0.14 & $2.03^{*}$ \\
\hline & Fuel-adapted & $0.011 \times$ Extraction distance & 0.88 & $3.30^{*}$ \\
\hline \multirow[t]{2}{*}{ Unload (min $\left.\mathrm{m}^{-3}\right)$} & Conventional & $0.54-0.0084 \times$ Load volume & 0.37 & 0.41 \\
\hline & Fuel-adapted & $0.48-0.0039 \times$ Load volume & 0.10 & 0.41 \\
\hline \multirow[t]{2}{*}{ Unload (min) } & Conventional & $1.86+0.27 \times$ Load volume & 0.79 & $6.02^{*}$ \\
\hline & Fuel-adapted & $1.25+0.33 \times$ Load volume & 0.76 & $7.1^{*}$ \\
\hline \multirow[t]{2}{*}{$\begin{array}{l}\text { Moving during } \\
\text { unloading (min) }\end{array}$} & Conventional & $-0.17+0.18 \times$ Product number & 0.48 & $0.042^{*}$ \\
\hline & Fuel-adapted & $-0.37+0.37 \times$ Product number & 0.74 & $0.25^{*}$ \\
\hline
\end{tabular}

\footnotetext{
* Significantly different mean elemental times between sites
} 
forwarder cycle time was $25.8 \mathrm{~min}$ for the Conventional operation and 29.3 min for the Fuel-adapted operation, and forwarder productivity was $38 \mathrm{~m}^{3} \mathrm{PMH}_{0}^{-1}$ for the Conventional operation and $34 \mathrm{~m}^{3} \mathrm{PMH}_{0}^{-1}$ for the Fueladapted operation which represented a $14 \%$ increase in cycle time and an $11 \%$ productivity reduction for the Fuel-adapted operation. Regression models and mean times for each time element and area are shown in Table 8.

\section{Logging residue extraction time consumption and productivity}

For both areas a linear regression model form gave the best fit to the cycle time data (Table 9).

Mean extraction distance and load weight were 245 $\mathrm{m}$ and 4.2 $\mathrm{Mg}$ (oven dry) (9 Mg (green)), and $226 \mathrm{~m}$ and 4.6 Mg (oven dry) (9.9 Mg (green)) in the Conventional and Fuel-adapted areas, respectively, and did not differ significantly between areas. Mean forwarder cycle times (Conventional: $38.9 \mathrm{~min}$; Fuel-adapted: $30.7 \mathrm{~min}$ ) were significantly different between areas. Fuel-adapted area Loading times were significantly longer than those in the Conventional area (min and $\mathrm{min} \mathrm{m}^{-3}$ ) (Table 10). No other elemental times were significantly different.

Regression models and mean times for forwarder time elements are shown in Table 10.

Mean forwarder productivity extracting LR was significantly greater in the Fuel-adapted area (Table 11).

No significant relationships between forwarder LR productivity and either load weight or extraction distance were found for either area. There was little productivity variation among forwarder cycles as increases in load weights were accompanied by a corresponding increase in cycle times.

\section{Costs}

Costs to harvest and extract logs and LR to roadside were calculated from machine costs and machine productivity (Table 12).

TABLE 9. Forwarder cycle time regression coefficients and fit statistics extracting logging residue

\begin{tabular}{llccc}
\hline Site & \multicolumn{1}{c}{ Model } & Sample size & RMSE & R $^{2}$ \\
\hline Conventional & Cycle time $=8.0+7.4 \times$ Load weight & 14 & 5.3 & 0.54 \\
Fuel-adapted & Cycle time $=-0.55+6.86 \times$ Load weight & 20 & 3.42 & 0.37 \\
\hline
\end{tabular}

TABLE 10. Regression models, associated $\mathrm{R}^{2}$ values and elemental times for forwarder time elements (extracting LR) at the Conventional and Fuel-adapted study sites.

\begin{tabular}{|c|c|c|c|c|}
\hline Time element & Site & Regression & $\mathbf{R}^{2}$ & $\begin{array}{l}\text { Mean time } \\
(\mathrm{min})\end{array}$ \\
\hline \multirow[t]{2}{*}{ Travel empty (min) } & Conventional & No significant relationship & - & 1.91 \\
\hline & Fuel-adapted & No significant relationship & - & 2.26 \\
\hline \multirow{2}{*}{$\begin{array}{l}\text { Loading (min Mg } \\
\text { (green) }^{-1} \text { ) }\end{array}$} & Conventional & No significant relationship & - & $6.06^{*}$ \\
\hline & Fuel-adapted & No significant relationship & - & $3.81^{*}$ \\
\hline \multirow[t]{2}{*}{ Loading (min) } & Conventional & $0.53+5.93 \times$ Load weight & 0.54 & $25.3^{*}$ \\
\hline & Fuel-adapted & No significant relationship & - & $17.4^{*}$ \\
\hline \multirow{2}{*}{$\begin{array}{l}\text { Moving during } \\
\text { loading (min) }\end{array}$} & Conventional & No significant relationship & - & 0.62 \\
\hline & Fuel-adapted & No significant relationship & - & 0.44 \\
\hline \multirow[t]{2}{*}{ Travel loaded (min) } & Conventional & $0.77+0.0074 \times$ Extraction distance & 0.37 & 2.58 \\
\hline & Fuel-adapted & $0.58+0.0079 \times$ Extraction distance & 0.51 & 2.36 \\
\hline \multirow{2}{*}{$\begin{array}{l}\text { Unload (min Mg } \\
\text { (green) }^{-1} \text { ) }\end{array}$} & Conventional & No significant relationship & - & 2.05 \\
\hline & Fuel-adapted & No significant relationship & - & 1.81 \\
\hline \multirow[t]{2}{*}{ Unload (min) } & Conventional & $1.1+1.79 \times$ Load weight & 0.44 & 8.52 \\
\hline & Fuel-adapted & $-6.2+3.19 \times$ Load weight & 0.42 & 8.31 \\
\hline
\end{tabular}

\footnotetext{
* Significantly different mean elemental times between sites
} 
TABLE 11. Mean forwarder productivity extracting $\mathrm{LR}\left(\mathrm{Mg} \mathrm{PMH}_{0}^{-1}\right)$ at the Conventional and Fuel-adapted study sites.

\begin{tabular}{lcc}
\hline & \multicolumn{2}{c}{ Forwarder productivity $\left(\mathbf{M g} \mathbf{P} \mathbf{M H}_{\mathbf{0}}{ }^{-1}\right)$} \\
\hline Site & Oven dry weight & Green weight \\
Conventional & 6.5 & 14.0 \\
Fuel-adapted & 9.0 & 19.4 \\
\hline
\end{tabular}

TABLE 12. Harvester and forwarder (logs and LR) costs for the Conventional and Fuel-adapted study sites. Total cost is the cost to harvest and extract 1 cubic metre of logs and $1 \mathrm{Mg}$ (green) of LR to roadside.

\begin{tabular}{|c|c|c|c|c|c|c|}
\hline \multirow[t]{2}{*}{ Site } & \multicolumn{2}{|c|}{ Harvester } & \multicolumn{2}{|c|}{ Forwarder (logs) } & \multirow{2}{*}{$\begin{array}{l}\text { Forwarder (LR) } \\
\text { AUD Mg (green)-1 }\end{array}$} & \multirow{2}{*}{$\begin{array}{c}\text { Total cost } \\
\text { AUD } \mathrm{m}^{-3}+\text { AUD Mg } \\
{\text { (green) })^{-1}}^{\text {ge }}\end{array}$} \\
\hline & AUD $\mathrm{PMH}_{0}^{-1}$ & AUD $\mathrm{m}^{-3}$ & AUD $\mathrm{PMH}_{0}^{-1}$ & AUD $\mathrm{m}^{-3}$ & & \\
\hline Conventional & 124.50 & 3.20 & 102.50 & 4.80 & 13.00 & 21.00 \\
\hline Fuel-adapted & 124.50 & 3.80 & 102.50 & 5.40 & 9.40 & 18.50 \\
\hline
\end{tabular}

\section{Discussion}

Harvester time consumption and productivity

Tree volume was the major factor determining harvester productivity in the study, as has been reported in many previous studies (e. g. Jiroušek et al. 2007; Nurminen et al. 2006; Strandgard et al. 2013; Walsh \& Strandgard 2014). Harvester productivity in the Conventional area was similar to that recorded by Jiroušek et al. (2007) and Walsh et al. (2014) in studies where the mean tree volume. was comparable with values observed here.

Harvester productivity was significantly less when harvesting the Fuel-adapted area compared with the Conventional area. The productivity reduction resulted from significantly longer cycle times in the Fuel-adapted area caused by significantly longer Moving/Positioning and Felling elemental times. The increased cycle and elemental times were largely related to lack of operator experience in felling trees using the fuel-adapted harvesting method. Moving/Positioning times increased because the operator took longer to select the next tree to be felled and to position the head to fell the tree in the correct direction. Felling times increased because each tree was moved alongside the harvester for processing while falling, whereas in the Conventional area trees were felled with little movement from where they stood. Processing would also often commence in the Conventional area while the tree was falling.

\section{Forwarder time consumption and productivity ex- tracting logs}

In both areas load volume, extraction distance and log number were significantly associated with the variation in forwarder productivity.

Forwarder productivity reported by Tiernan et al. (2004) was similar to the current study for the same mean extraction distance, load volume and similar site conditions. Greater mean tree volumes and shorter extraction distances than those in the current study resulted in considerably increased forwarder productivity for two trials in mature $P$. radiata final harvest operations under similar site conditions (Ghaffariyan et al. 2015): $86 \mathrm{~m}^{3} \mathrm{PMH}_{0}^{-1}$ and (Walsh and Strandgard 2014): 93 $\mathrm{m}^{3} \mathrm{PMH}_{0}^{-1}$ ). Forwarder productivity

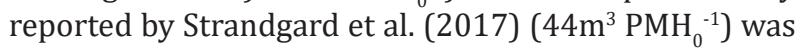
also greater than that in the current study due to greater mean log volumes but the difference in productivity was considerably less due to longer extraction distances in the Strandgard et al. (2017) study.

Longer cycle times in the Fuel-adapted area were associated with a significant reduction in forwarder productivity compared with the Conventional area. The longer extraction distances in the Fuel-adapted area increased Travel loaded times, accounting for some of the difference in cycle times. Other factors were the significantly longer Loading ( $\mathrm{min}$ ), Unloading ( $\mathrm{min}$ ) and Moving during loading times in the Fuel-adapted area. Loading times in the Fuel-adapted area were impacted by the poorer product separation which often required the operator to sort through log piles to select the desired product type(s). To reduce infield sorting, the forwarder operator increased the number of mixed-product loads. Although products were predominantly kept separate on the forwarder bunk, some sorting was required at roadside resulting in increased Unloading (min) and Moving during unloading times in the Fuel-adapted area. The longer Moving during loading time in the Fueladapted area resulted from differences in the loading method between the areas. In the Fuel-adapted area, the forwarder was required to stop at each discrete log pile to load before moving to the next log pile. Conversely, in the Conventional area the continuous row of logs laid out alongside the extraction path predominantly allowed the 
forwarder to travel slowly while loading logs.

As expected, Loading time (min) in both areas was positively related to load volume and number of logs. Loading time $\left(\mathrm{min}^{-3}\right)$ also increased in both areas as the number of logs increased. As greater numbers of logs often resulted from loading smaller logs, the increased Loading time reflected the greater time required to load smaller logs (Danilović et al. 2014; Nurminen et al. 2006). Similarly, the apparently anomalous result that Loading times $\left(\mathrm{min} \mathrm{m}^{-3}\right)$ and Unloading times (min $\mathrm{m}^{-3}$ ) decreased with increasing load volume reflected the inverse relationship between number of logs and load volume (Kellogg \& Bettinger 1994). Unloading times (min) increased with increasing load volume, as would be expected. Travel empty time was significantly associated with extraction distance in the Conventional area only, whereas Travel loaded time was significantly associated with extraction distance in both areas, though in all cases the relationships were weak.

Reduced harvester and forwarder productivity when producing logs from the Fuel-adapted area was likely to reflect a learning effect as reported by Purfürst (2010) and Lapointe and Robert (2000). Unlike those studies, the operators in this study were experienced which suggested that tacit knowledge the operators had acquired was of limited use when learning the fueladapted harvesting approach and may have even been a hindrance as the operators had to "relearn" how to perform their tasks.

\section{Forwarder time consumption and productivity extracting logging residue}

Forwarder cycle times extracting LR were positively related to load weight in both areas. Extraction distance was not a significant variable because travel times (loaded and empty) were a minor part of total cycle times (Conventional 11.5\%, Fuel-adapted 15.1\%). Significantly shorter cycle times in the Fuel-adapted area resulted in forwarder productivity being significantly greater in this area. The shorter cycle times in the Fuel-adapted area resulted from significantly shorter Loading times which reflected the relative ease of loading LR from piles compared with loading scattered LR from the ground.

Forwarder load weights in both areas were similar to those reported by Nurmi (2007), however, forwarder productivity in the current study was considerably greater which was the result of longer extraction distances increasing cycle times in the Nurmi (2007) study.

LR load weights in the study reported here were approximately $50 \%$ of the forwarder's weight capacity. Forwarders with extended load bunks commonly used in Sweden and Finland are able to carry LR loads up to approximately $75 \%$ of the forwarder's weight capacity (Eliasson et al. 2011). Modified forwarder grapples can also be used to load and unload LR faster than a conventional log grapple (Eliasson \& Nordén 2010).

\section{Logging residue yields}

Total LR quantities at both sites in the current study were at the middle of the range of those measured at sixteen
CTL final harvest operations in mature Australian Pinus radiata plantations (30 to $155 \mathrm{Mg} \mathrm{ha}^{-1}$ ) (Ghaffariyan 2013; Ximenes et al. 2012). Factors such as product specifications, stand density, site type and tree age (Räisänen \& Nurmi 2011) were likely to have caused the variation in LR quantities between these sites.

The LR recovery rate in the Fuel-adapted area was similar to the mean recovery rate reported by Thiffault et al. (2011) for studies in Nordic countries (72\%) while the rate in the Conventional area was similar to that reported by Thiffault et al. (2011) for studies in nonNordic countries where loose LR was gathered from the cutblock (32\%). The higher LR recovery rate from the Fuel-adapted area was likely to have resulted from piling of LR which allowed the forwarder operator to extract small residue pieces that would be impractical to pick up when scattered on the ground. This is consistent with findings reported in previous residue recovery studies (Nurmi 2007; Thiffault et al. 2015).

LR can contain a significant proportion of the site's nutrient capital (Madgwick \& Webber 1987). A worldwide meta-study of harvest residue removal trials found that removal of harvest residues, particularly when foliage was removed, often reduced subsequent tree growth (Achat et al. 2015). To mitigate the impact of LR removal on site productivity, LR foliage content can be reduced through infield drying (Nilsson et al. 2013), higher levels of fertiliser can be applied (Jones et al. 2011) or minimum levels of LR retention can be specified as is done in Finland (Abbas et al. 2011) and parts of the United States (Briedis et al. 2011).

\section{Costs}

Harvester costs were comparable to those reported by Walsh and Strandgard (2014) and Ghaffariyan et al. (2015) while forwarder extraction costs (logs) were approximately double those reported in these studies due to differences in productivity.

The LR forwarder extraction cost reported by Kärhä and Vartiamäki (2006) was $\sim$ AUD10 Mg (green) ${ }^{-1}$ (exchange rate $€ 1=$ AUD1.58) which was similar to that in the Fuel-adapted area. Bergström and Di Fulvio (2014) reported a cost of $\sim$ AUD13 Mg (green) ${ }^{-1}$ (exchange rate SEK1 $=$ AUD0.15) which was similar to that in the Conventional area. Neither of these studies stated whether the LR was piled or scattered.

Total costs for log and LR harvest and extraction were less in the Fuel-adapted area as the lower cost for LR extraction to roadside offset the higher harvester and forwarder (logs) costs.

\section{Conclusions}

Accumulating LR in piles in the Fuel-adapted area enabled a greater yield of LR to be extracted and significantly increased forwarder productivity and decreased costs when extracting LR compared with extracting scattered LR in the Conventional area. However, harvester and forwarder productivity when processing and extracting logs was significantly reduced and costs were increased in the Fuel-adapted area compared with the Conventional area. Swedish experience found similar productivity 
reductions to be the result of lack of operator experience with fuel-adapted harvesting. This suggested that continued use of fuel-adapted harvesting in Australia is likely to see differences in machine productivity and costs between fuel-adapted and conventional harvesting operations reduce over time. Overall the results show that adoption of fuel-adapted harvesting in Australia could reduce the delivered costs of LR, increasing its viability as a biofuel. However, primary transport cost is only one component of the LR delivered costs and needs to be considered in combination with methods to reduce other supply chain costs, particularly secondary transport costs which can make up a large proportion of the delivered costs of LR.

Experience in Nordic countries has shown that further significant forwarder productivity gains when extracting LR can be made through using forwarders with extended load bunks and residue specific grapples. Investigation of these forwarder modifications is warranted in Australia to determine their impact on delivered LR and logs costs with different species and larger harvest units.

Evidence from previous trials has shown that removing most or all of the LR from a logging site can significantly reduce subsequent tree growth. The high proportion of total LR removed from the Fuel-adapted area in the current study highlights that standards or guidelines for minimum proportions of LR to be retained may need to be considered for regions or countries without existing rules to maintain site productivity.

\section{Competing interests}

The authors declare that they have no competing interests.

\section{Authors' contributions}

MS was the primary author, undertook the analyses, and assisted with the field measurements. RM supervised the field measurements and provided critical revisions of the manuscript. Both authors read and approved the final manuscript.

\section{Funding}

The authors acknowledge the funding from the University of the Sunshine Coast and the industry partners of the Australian Forest Operations Research Alliance.

\section{Acknowledgements}

The authors would like to thank staff from Wespine, the Plantation Logging Company and the Forest Products Commission without whom this study would not have been possible and Julia Bergamin, Sao Paulo State University, for her assistance in field data collection.

\section{Availability of data and materials}

The data belongs in full to the University of the Sunshine Coast and this publication forms part of a PhD thesis project developed by Mr. Martin Strandgard at the University of Tasmania. Any request to use the original data for publication purposes requires a specific project proposal to be approved by the University of the Sunshine Coast for any interested scientist in making use of the datasets.

\section{References}

Abbas, D., Current, D., Phillips, M., Rossman, R., Hoganson, H., \& Brooks, K. N. (2011). Guidelines for harvesting forest biomass for energy: A synthesis of environmental considerations. Biomass \& Bioenergy, 35(11), 4538-4546.

Achat, D., Deleuze, C., Landmann, G., Pousse, N., Ranger, J., \& Augusto, L. (2015). Quantifying consequences of removing harvesting residues on forest soils and tree growth-A meta-analysis. Forest Ecology and Management, 348, 124-141.

AEBIOM (2013). European Bioenergy Outlook 2013. Brussels: European Biomass Association.

Belart, F., Sessions, J., Leshchinsky, B., \& Murphy, G. (2017). Economic implications of moisture content and logging system in forest harvest residue delivery for energy production: a case study. Canadian Journal of Forest Research, 47(4), 458466.

Bergström, D., \& Di Fulvio, F. (2014). Comparison of the cost and energy efficiencies of present and future biomass supply systems for young dense forests. Scandinavian Journal of Forest Research, 29(8), 793-812. doi:10.1080/02827581.2014.976590

Briedis, J., Wilson, J., Benjamin, J., \& Wagner, R. (2011). Logging residue volumes and characteristics following integrated roundwood and energy-wood whole-tree harvesting in Central Maine. Northern Journal of Applied Forestry, 28(2), 66-71. https:// doi.org/10.1093/njaf/28.2.66

Brown, M., Guimier, D., Mercier, S., Provencher, Y., \& Turcotte, P. (2002). MultiDAT and Opti-grade: Two knowledge-based electronic solutions for managing forestry operations more efficiently. In L Kellogg, B Spong, \& P Licht (Eds.), Woodfor Africa Forest Engineering Conference, Pietermaritzburg, South Africa, July 2-3; pp. 45-49.

Cambi, M., Certini, G., Neri, F., \& Marchi, E. (2015). The impact of heavy traffic on forest soils: a review. Forest Ecology and Management, 338, 124-138.

Caputo, A. C., Palumbo, M., Pelagagge, P. M., \& Scacchia, F. (2005). Economics of biomass energy utilization in combustion and gasification plants: effects of logistic variables. Biomass \& Bioenergy, 28(1), 35-51. doi:http://dx.doi.org/10.1016/j. biombioe.2004.04.009

Cuchet, E., Roux, P., \& Spinelli, R. (2004). Performance of a logging residue bundler in the temperate forests of France. Biomass and Bioenergy, 27(1), 31-39. doi:https://doi.org/10.1016/j. biombioe.2003.10.006

Danilović, M., Stojnić, D., Karić, S., \& Sučević, M. (2014). Transport of technical roundwood by forwarder and tractor assembly from poplar plantations. 
Nova mehanizacija šumarstva: Časopis za teoriju $i$ praksu šumarskoga inženjerstva, 35, 11-21.

Eliasson, L., Brunberg, T., \& Lundström, H. (2011). Productivity when forwarding fresh and dried logging residues. . Paper presented at the FORMEC 2011, Graz, Austria, October 9-13, 2011.

Eliasson, L., \& Nordén, B. (2010). A new grapple with potential to increase productivity. (Efficient forest fuel supply systems. Composite report from a four year R \& D programme 2007-2010). Uppsala: Skogforsk.

Ghaffariyan, M. R. (2013). Remaining slash in different harvesting operation sites in Australian plantations. Silva Balcanica, 14(1), 83-93.

Ghaffariyan, M. R., Spinelli, R., Magagnotti, N., \& Brown, M. (2015). Integrated harvesting for conventional log and energy wood assortments: a case study in a pine plantation in Western Australia. Southern Forests: a Journal of Forest Science, 77(4), 249-254. doi:10.2989/20702620.2015.1052946

Gold, S., \& Seuring, S. (2011). Supply chain and logistics issues of bio-energy production. Journal of Cleaner Production, 19(1), 32-42. doi:https://doi. org/10.1016/j.jclepro.2010.08.009

Gregg, J. S., \& Smith, S. J. (2010). Global and regional potential for bioenergy from agricultural and forestry residue biomass. Mitigation and Adaptation Strategies for Global Change, 15(3), 241-262.

Jacobson, S., \& Filipsson, J. (2013). Spatial distribution of logging residues after final felling - comparison between forest fuel adapted final felling and conventional final felling methods. Arbetsrapport nr. 797, Sweden: Skogforsk.

Jiroušek, R., Klvač, R., \& Skoupy, A. (2007). Productivity and costs of the mechanised cut-to-length wood harvesting system in clear-felling operations. Journal of Forest Science, 53, 476-482.

Jones, H., Beets, P., Kimberley, M., \& Garrett, L. (2011). Harvest residue management and fertilisation effects on soil carbon and nitrogen in a 15-yearold Pinus radiata plantation forest. Forest Ecology and Management, 262(3), 339-347. https://doi. org/10.1016/j.foreco.2011.03.040

Junginger, M., Faaij, A., Björheden, R., \& Turkenburg, W. C. (2005). Technological learning and cost reductions in wood fuel supply chains in Sweden. Biomass and Bioenergy, 29(6), 399-418. doi:http://dx.doi. org/10.1016/j.biombioe.2005.06.006

Kärhä, K., \& Vartiamäki, T. (2006). Productivity and costs of slash bundling in Nordic conditions. Biomass and Bioenergy, 30(12), 1043-1052. doi:http:// dx.doi.org/10.1016/j.biombioe.2005.12.020

Kellogg, L. D., \& Bettinger, P. (1994). Thinning productivity and cost for a mechanized cut-to-length system in the Northwest Pacific coast region of the USA. Journal of Forest Engineering, 5, 43-54.
Kizha, A. R., \& Han, H.-S. (2016). Processing and sorting forest residues: Cost, productivity and managerial impacts. Biomass and Bioenergy, 93, 97-106.

Lapointe, J.-F., \& Robert, J.-M. (2000). Using VR for efficient training of forestry machine operators. Education and Information Technologies, 5(4), 237250.

Madgwick, H., \& Webber, B. (1987). Nutrient removal in harvesting mature Pinus radiata. New Zealand Journal of Forestry, 32(3), 15-18.

Mani, S., Sokhansanj, S., Bi, X., \& Turhollow, A. (2006). Economics of producing fuel pellets from biomass. Applied Engineering in Agriculture, 22(3), 421-426. doi:https://doi.org/10.13031/2013.20447

Miyata, E. S. (1980). Determining fixed and operating costs of logging equipment. General Technical Report NC-55. St. Paul, MN, USA: U.S. Dept. of Agriculture, Forest Service, North Central Forest Experiment Station.

Motulsky, H., \& Christopoulos, A. (2004). Fitting models to biological data using linear and nonlinear regression: a practical guide to curve fitting. Oxford, UK: Oxford University Press.

Nilsson, B., Blom, Å., \& Thörnqvist, T. (2013). The influence of two different handling methods on the moisture content and composition of logging residues. Biomass \& Bioenergy, 52, 34-42. doi:https://doi. org/10.1016/j.biombioe.2013.02.026

Nurmi, J. (2007). Recovery of logging residues for energy from spruce (Pices abies) dominated stands. Biomass \& Bioenergy, 31(6), 375-380. doi:http:// dx.doi.org/10.1016/j.biombioe.2007.01.011

Nurminen, T., Korpunen, H., \& Uusitalo, J. (2006). Time consumption analysis of the mechanized cut-tolength harvesting system. Silva Fennica, 40(2), 335-363.

Parikka, M. (2004). Global biomass fuel resources. Biomass and Bioenergy, 27(6), 613-620.

Purfürst, F. T. (2010). Learning curves of harvester operators. Croatian Journal of Forest Engineering: Journal for Theory and Application of Forestry Engineering, 31(2), 89-97.

Räisänen, T., \& Nurmi, J. (2011). Impacts of changing the minimum diameter of roundwood on the accumulation of logging residue in first thinnings of Scots pine and Norway spruce. Biomass \& Bioenergy, 35(7), 2674-2682. doi:http://dx.doi. org/10.1016/j.biombioe.2011.03.002

Rodriguez, L. C., May, B., Herr, A., \& O'Connell, D. (2011). Biomass assessment and small scale biomass fired electricity generation in the Green Triangle, Australia. Biomass \& Bioenergy, 35(7), 2589-2599. doi:http://dx.doi.org/10.1016/j. biombioe.2011.02.030

Snowdon, P. (1991). A ratio estimator for bias correction in logarithmic regressions. Canadian Journal of Forest Research, 21, 720-724. 
Strandgard, M., Mitchell, R., \& Acuna, M. (2017). Time consumption and productivity of a forwarder operating on a slope in a cut-to-length harvest system in a Pinus radiata D.Don pine plantation. Journal of Forest Science, 63, 324-330.

Strandgard, M., Walsh, D., \& Acuna, M. A. (2013). Estimating harvester productivity in Pinus radiata plantations using StanForD stem files. Scandinavian Journal of Forest Research, 28, 73-80.

Thiffault, E., Béchard, A., Paré, D., \& Allen, D. (2015). Recovery rate of harvest residues for bioenergy in boreal and temperate forests: A review. Wiley Interdisciplinary Reviews: Energy and Environment, 4(5), 429-451. doi:10.1002/wene.157

Thiffault, E., Hannam, K. D., Paré, D., Titus, B. D., Hazlett, P. W., Maynard, D. G., \& Brais, S. (2011). Effects of forest biomass harvesting on soil productivity in boreal and temperate forests-a review. Environmental Reviews, 19(1), 278-309.

Tiernan, D., Zeleke, G., Owende, P. M. O., Kanali, C. L., Lyons, J., \& Ward, S. M. (2004). Effect of working conditions on forwarder productivity in cutto-length timber harvesting on sensitive forest sites in Ireland. Biosystems Engineering, 87(2), 167-177. doi:http://dx.doi.org/10.1016/j. biosystemseng.2003.11.009

Walsh, D., \& Strandgard, M. (2014). Productivity and cost of harvesting a stemwood biomass product from integrated cut-to-length harvest operations in Australian Pinus radiata plantations. Biomass \& Bioenergy, 66, 93-102.

Walsh, D., Strandgard, M., \& Carter, P. (2014). Evaluation of the Hitman PH330 acoustic assessment system for harvesters. Scandinavian Journal of Forest Research, 29(6), 593-602. doi:10.1080/02827581 .2014 .953198

Wolfsmayr, U. J., \& Rauch, P. (2014). The primary forest fuel supply chain: A literature review. Biomass \& Bioenergy, 60, 203-221. doi:https://doi. org/10.1016/j.biombioe.2013.10.025

Ximenes, F., Ramos, J., Bi, H., Cameron, N., Singh, B. P., \& Blasi, M. (2012). Determining biomass in residues following harvest in Pinus radiata forests in New South Wales. Canberra, Australia: Rural Industries Research and Development Corporation.

Yemshanov, D., McKenney, D. W., Fraleigh, S., McConkey, B., Huffman, T., \& Smith, S. (2014). Cost estimates of post harvest forest biomass supply for Canada. Biomass \& Bioenergy, 69, 80-94. doi:http://dx.doi. org/10.1016/j.biombioe.2014.07.002 